\title{
The Optimal Size of a Political Party Based on the Shapley-Shubik Power Index シャープレイ・シュービック投票力指数に基づく政党の最適規模
}

\author{
Yuuki Maruyama
}

\begin{abstract}
Shapley-Shubik Power Index per person (SSPIPP) is defined as the ratio of a political party's ShapleyShubik Power Index in Parliament to the number of people who voted for the party. SSPIPP can be regarded as the political power each of them has. This model reveals the relationship between the party size and SSPIPP and shows it in a graph. The graph is M-shaped and reveals the optimal party size that maximizes SSPIPP. According to this model, the more votes required to pass bills in Parliament, the smaller the optimal party size becomes. This model also predicts that in countries which require a supermajority vote to pass bills, party system fragmentation tends to last long.
\end{abstract}

議会における政党のシャープレイ・シュービック投票力指数（SSPI）を、その党へ投票した国民の人数 で割った值を、一人当たりシャープレイ・シュービック投票力指数（SSPIPP）と定義する。その党に投 票した人にとって SSPIPP は、国政に対して自分が持つ影響力の大きさとみなせる。政党の規模によっ て SSPIPP がどのように変化するかを分析し、この両者の関係をグラフで表す。グラフは M 字型のグラ フとなり、SSPIPP を最大化する最適な政党規模を明らかにしている。また、法案可決のためにより多く の賛成票が必要な議会 (可決要件が高い議会) ほど、最適な政党規模が小さくなることが示される。さら にこの分析に基づき、可決に supermajority の賛成票を必要とする国は小党分立状態が固定化しやすい ことが示唆される。

\section{1 序論}

議会における政党のシャープレイ・シュービック投票力指数(SSPI) というのは、政党の議席割合や政党の 支持者の人数と比例しない。政党の支持者としては、自党の SSPI は大きいほうが望ましい。ただ、自党 の支持者の人数が高いほど、自党の党内意思決定における自分の投票力は小さくなってしまう。すなわ ち、議会における自党の SSPI が高いほど望ましく、自党の支持者の人数が少ないほど望ましい。 党内意思決定においては党の支持者（党員）が一人当たり一票を持つとする（例えば多くの国の党首選で は実際そのようになっている）と、党内意思決定における自らの投票力指数は、党の支持者の人数の逆数 で表せる。この場合、国政に対して自分が持つ影響力の大きさというのは、自党の議会における SSPI を、 自党へ投票した国民（自党の支持者）の人数で割ったものだといえるだろう。今回はこの值を、一人当た りシャープレイ・シュービック投票力指数（SSPIPP） と定義する。政党の支持者は、自党の政治家に対 して SSPIPP の最大化を働きかけると考えられる。今回のモデルでは、SSPIPP を最大化するためには どのくらいの規模の政党を目指すのが合理的かについて分析する。また、この分析に基づき、国にとって 法律の可決要件はどのくらいの值に設定す心゙きか、などについて考察する。 


\section{2 モデル}

議会において法律の可決に必要な賛成票の割合を $\mathrm{s}$ とする（厳密には、s を超える割合の賛成票で可決さ れるとする)。ただし、相反する二つの法律が同時に可決されないようにするために最低限、

$\frac{1}{2} \leq s \leq 1$ は満たされているとする。

自党以外の党の数を $\mathrm{n}$ と、単純化のためにそれら $\mathrm{n}$ 個の党の議席割合は全て等しく $\mathrm{q}$ とる。よって、 自党の議席割合を $\mathrm{Q}$ とすると、 $\mathrm{Q}+\mathrm{nq}=1$ となる（この式はつまり、自党が支持者を増やし $\mathrm{Q}$ を増加させ る際は、残りの $\mathrm{n}$ 党から均等に支持者を引き寄せると仮定することを意味している)。

自党のSSPI を求める。
(1) $0 \leq \mathrm{Q}<1-\mathrm{s}$
(2) $1-\mathrm{s} \leq \mathrm{Q}<\mathrm{s}$
(3) $\mathrm{s} \leq \mathrm{Q} \leq 1$
の 3 通りの場合に分けて考える。

$x$ を実数として、 $[x]$ を $x$ 以下の最大の整数と定義する。今回の分析では $\mathrm{n}$ が大きいという仮定を置いて 近似を用いる。

（1）のとき、

$(\mathrm{n}+1)$ 個の政党の順列のうち自党がピボットになるのは、自党が $\left(\left[\frac{s-Q}{q}\right]+2\right)$ 番目から $\left(\left[\frac{s}{q}\right]+1\right)$ 番目までの 時である。故に

$$
\begin{aligned}
\text { SSPI } & =\frac{n !}{(n+1) !}\left\{\left(\left[\frac{s}{q}\right]+1\right)-\left(\left[\frac{s-Q}{q}\right]+1\right)\right\} \\
& \fallingdotseq \frac{1}{n+1}\left(\frac{s}{q}-\frac{s-Q}{q}\right) \\
& =\frac{n}{n+1} \times \frac{Q}{1-Q} \\
& \doteqdot \frac{Q}{1-Q}
\end{aligned}
$$

(2)のとき、

自党は拒否権を持つ。(n+1)個の政党の順列のうち自党がピボットになるのは、自党が $\left(\left[\frac{s-Q}{q}\right]+2\right)$ 番目か ら(n+1)番目までの時である。故に

$$
\begin{aligned}
\text { SSPI } & =\frac{n !}{(n+1) !}\left\{(n+1)-\left(\left[\frac{s-Q}{q}\right]+1\right)\right\} \\
& \doteqdot \frac{1}{n+1}\left(n-\frac{s-Q}{q}\right) \\
& =\frac{n}{n+1} \times \frac{1-s}{1-Q} \\
& \doteqdot \frac{1-s}{1-Q}
\end{aligned}
$$


(3)のとき、

SSPI $=1$

次に SSPIPP を求める。国の人口を $\mathrm{N}$ 人とする。議会選挙は比例代表制であると想定すると、議会にお ける政党の議席割合はその党へ投票した国民の人数に比例することになる。この場合、党内意思決定に おける個人の投票力は $\frac{1}{N Q}$ であり、SSPIPP はSSPI $\mathrm{NQ}$ で割った值となるため、

（1）のとき、

$\mathrm{SSPIPP} \fallingdotseq \frac{1}{N} \times \frac{1}{1-Q}$

(2)のとき、

$\mathrm{SSPIPP} \fallingdotseq \frac{1}{N} \times \frac{1-s}{Q(1-Q)}$

(3)のとき、

$\mathrm{SSPIPP} \fallingdotseq \frac{1}{N} \times \frac{1}{Q}$

となる。

SSPIPP の值についてグラフで示す。例として、s=0.6 の場合を Figure 1、s=0.8 の場合を Figure 2 に示 す。

Figure 1: $\quad$ SSPIPP $\quad(\mathrm{s}=0.6)$

Figure 2 : $\quad$ SSPIPP $\quad(\mathrm{s}=0.8)$
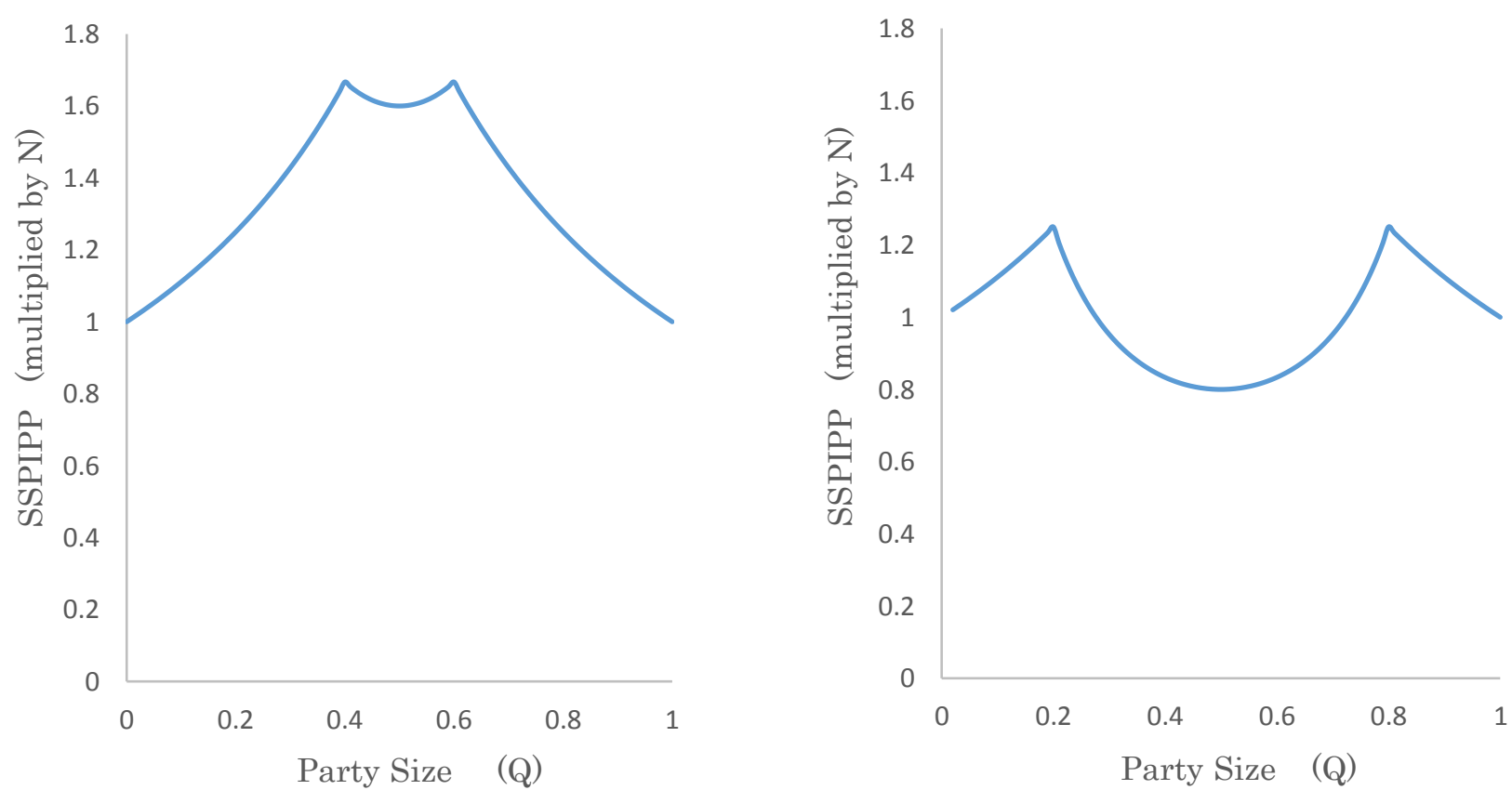
多くの場合、政党の規模は $0 \leq \mathrm{Q}<\frac{1}{2}$ であるが、この範囲においては $\mathrm{Q}=1$ - $\mathrm{s}$ のときに SSPIPP は最大 值をとる。政党やその支持者が、発言力の指標である SSPIPP の最大化を目標とすると仮定すると、各 党は $\mathrm{Q}=1-\mathrm{s}$ の政党規模を目指寸のが合理的戦略となる。また、sが小さい議会ほど各政党にとって党 勢拡大のインセンティブが高いといえるだろう。

\section{3 考察}

以上、SSPIPP の算出を通して、政党の最適規模について分析した。政党の戦略的行動について考察す る。

議会の法律の可決要件が低い場合、各政党の支持者にとって自党の規模が大きくなることが望ましい。 各政党の支持者は多少自党の支持政策の中道化を許してでも、多くの浮動層に投票してもらえるような 大政党を目指すであろう（中位投票者定理の設定に近づくとも言える）。

逆に、supermajority voting rule などで可決要件が高い議会の場合、自党の規模が大きくなりすぎる と支持者にとっては一人当たりの投票力指数は低下してしまうことになるため、拒否権を持てる程度の 政党規模で抑えておくことが望ましい。党勢拡大よりも既存の支持者を重視する傾向が強いため、小党 分立状態が常態化しやすく、党の支持政策の中道化も行われにくいと言えるだろう。可決要件が高いう えに小党分立傾向があるため、二重の意味で法律が可決されにくいと考えられる。

一般に、可決要件の高い政治制度は少数意見を重んじる制度であるとして好意的に見られる傾向があ るが、小党分立状態 (それに伴う政治の不安定性) の回避や政治の中道化という観点から見れば、むしろ 可決要件を高くしすぎないほうが望ましいのかもしれない。

\section{4 補遺}

二院制というのは可決要件が高いことと実質的に同義であり、今回の分析に基づけば、政党構成の小党 分立状態が固定化しやすい政治制度と考えられる。ただ、二院制であっても、片方の議院の可決要件が $\frac{1}{2}$ 以上でありさえすればもう一方の議院の可決要件は $\frac{1}{2}$ 以下にしても問題は発生しない。そういった措置 により、実質的な可決要件を下げることができる。

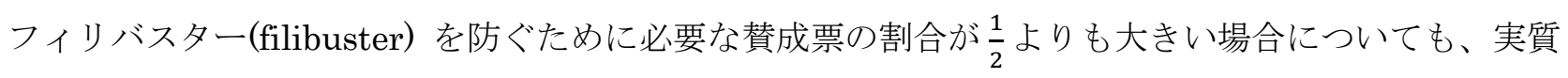
的に可決要件が高いと言えるだろう。

また今回は、党内意思決定における個人の投票力を、シャープレイ・シュービック投票力指数を用いて $\frac{1}{N Q}$ で表したが、もし Penrose square-root law のように $\sqrt{\frac{2}{\pi N Q}}$ で表すとすると結果は大きく異なるた め、注意が必要である。この場合、国政に対する各個人の投票力は、（1）の時に $\left.\sqrt{\frac{2}{\pi N}} \times \frac{\sqrt{Q}}{1-Q} 、 （ 2\right)$ の時に $\left.\sqrt{\frac{2}{\pi N}} \times \frac{1-s}{\sqrt{Q}(1-Q)} 、 （ 3\right)$ の時に $\sqrt{\frac{2}{\pi N}} \times \frac{1}{\sqrt{Q}} 、$ となる。 


\section{参考文献}

Kirsch, W. (2013). On Penrose's square-root law and beyond. In Power, Voting, and Voting Power: 30 Years After (pp. 365-387). Springer, Berlin, Heidelberg.

Shapley, L. S., \& Shubik, M. (1954). A method for evaluating the distribution of power in a committee system. American political science review, 48(3), 787-792. 